\title{
Tourism as Intercultural Business: Locating Concepts and Questioning Identities
}

\author{
Clara Sarmento*
}

\begin{abstract}
:
This paper approaches the topic of tourism as a global intercultural business, resorting to notions of culture, identity, representation and territory, among other concepts used in intercultural studies. Studying global tourism not only means thinking about it in terms of the world's economy, but also regarding issues of identity and difference, representation, heritage, history and transformation of geographic spaces into significant places. Exploring tourism as a world cultural phenomenon is a way of associating it with the ever-polemic concept of globalization, often understood as a manifestation of Western dominance. Thus, this paper will also address matters of ethics, power and cultural hegemony.

Addressing tourism as an intercultural business is both an opportunity and a challenge. The opportunity to develop routes of cultural tourism while empowering and engaging communities in the protection of cultural heritage; the challenge to enhance sustainable tourism, with an impact on employment, economic growth, poverty reduction, environmental protection and the general preservation of authenticity in culture and heritage. By recognizing the value of different sections of the community, cultural resources and heritage that could otherwise be seen as ordinary become exceptional. And the exceptional is what tourists seek, as opposed to the commonplace routine of everyday life.
\end{abstract}

Keywords: Intercultural, tourism, power, identity, discourse, development.

\section{Introduction.}

This paper approaches the topic of tourism as a global intercultural business, resorting to notions of culture, identity, representation and territory, among other concepts used in intercultural studies ${ }^{1}$. Studying global tourism not only means thinking about it in terms of the world's economy, but also regarding issues of identity and difference, representation, heritage, history and transformation of geographic spaces into significant places. Exploring tourism as a world cultural phenomenon is a way of associating it with the ever-polemic concept of globalization, often understood as a manifestation of Western dominance. Thus, this paper will also address matters of ethics, power and cultural hegemony. Indeed, international tourism increasingly offers a global formula, where local culture is shown as a mere display of colourful leisure for wealthy visitors to enjoy. Culture is adapted and reduced to the impact of light entertainment and aesthetic appeal, as in the

${ }^{1}$ This paper employs the concept of "intercultural" as a synonym for movement, communication, and encounter between cultures (ABDALLAH-PRETCEILLE, 2006; IBANEZ \& SAENZ, 2006; SARMENTO, 2010, 2014, 2016; DERVIN, GAJARDO \& LAVANCHY, 2011; HOLLIDAY, 2011, 2013; DERVIN \& GROSS, 2016; IMBERT, 2014). 
cases of moliceiro boat races in Portugal, capoeira martial art in Brazil, mendhi body art in Tunisia, bindi in India, or tango in Argentina.

We shall begin by attempting to define what we actually understand as tourism. Tourism is a leisure activity that directly contrasts with the daily procedures of paid or unpaid organized labour. Tourism involves an outward movement, a journey to places where one 'stays' but does not 'live'. Tourists' stays are temporary, and always aimed at returning home to an organized work routine. Visited places are different from those places where work and everyday life happen. In fact, this difference is the key characteristic that turns such places into desirable holiday destinations. Activities carried out while one is 'away' take on a different note or intensity from activities undertaken while one is 'at home': our outlook as tourists on the surrounding environment is much more intense than during the course of everyday life $^{2}$. The tourists' experience differs from the daily experience, at least regarding one of the following aspects: location, activity, landscape and sensory experience (URRY, 2002). Whether advertising alters our perception of holidays as an intense experience in different places or triggers already nurtured holiday expectations remains unclear. Notwithstanding, while there are historical and sociological variants on what tourism is, it is possible to describe some common features related to the social practice of tourism in the $21^{\text {st }}$ century, at least in Western economies whose societies have a clear and structured boundary between work and leisure. According to John Urry, in so-called modern societies, tourism is a legalized and organized leisure activity, which can be compared to its opposite facet, work, an activity that is also legalized and organized (URRY, 2002: 2 et seq.).

The definition of tourism is seen as a part of the Western common sense. It is one of Raymond Williams' “structures of feeling” (1961, 1976) or Paul duGay's "significant practices" (1997, 2007), produced by and for society, from a wide range of discourses that allow us to represent and communicate ideas about work, leisure, exoticism, everyday life, distance, pleasure, freedom, obligations and responsibilities, among other things. However, societies where people cannot travel because of a lack of resources, due to warfare or political reasons, or because of job demands or lack of transport will hardly see tourism in a similar fashion.

\section{Tourism: a brief overview of the business.}

Mass tourism has only become a trend in the last two hundred years. Mainly in North America and Europe, then gradually across the world, or nearly all of it, although, in practice, visiting other cultures in order to have intense or different experiences is not a new thing. In Ancient Rome, road infrastructures allowed the privileged elite to travel for work or leisure. The pursuit of intense religious experiences - or a simple escape from a mundane life - remained entirely associated with the pilgrimages of the Middle Ages. From the $13^{\text {th }}$ century, all over Europe, travellers would venture on long pilgrimages to religious

2 John Urry identified two observational models that can be aligned with the classic distinction between traveller and tourist: the romantic observation of the traveller and the collective observation of the tourist. Romantic observation requires solitude, privacy and a personal relationship with the object that is observed. Collective observation requires the constant presence of others, something that is critical to the creation of the Disneyworld carnival atmosphere, for example (URRY, 2002). 
places of their devotion, whilst staying in inns and monasteries along the way. In the $15^{\text {th }}$ century, travellers could already go as far as the Holy Land, departing from Venice. In the $18^{\text {th }}$ century, the Grand Tour established itself as a vehicle of cultural education for the sons of the British aristocracy. From the outset, this trip would be undertaken so that classical sites of Greece and Italy could be visited, including galleries, museums and monuments. In the $19^{\text {th }}$ century, the sons and also the daughters of the baute bourgeoisie would also embark on the Grand Tour, which became a more sensory and aesthetic experience of contemplating the sublime, often by revelling in natural landscapes. In the same century, the American elite also began crossing the Atlantic in order to travel across Europe, to visit its historical, cultural and natural sites. Nevertheless, before the $20^{\text {th }}$ century, all these examples of travel for pleasure and cultural enrichment could only be afforded by a wealthy and privileged few. Social tourism practices were only consolidated in the course of the $20^{\text {th }}$ century, taking up $40 \%$ of the time available for leisure. Vacationing then became a fixture of a Western lifestyle. According to the United Nations World Tourism Organization (UNWTO), international tourism escalated from a little more than one million tourists in 1959 to over a billion in 2014 .

A brief overview of late $20^{\text {th }}$ century and first decades of the $21^{\text {st }}$ century shows that Southeast Asia's growing economies such as Thailand, Malaysia and Singapore, have been particularly effective in attracting international visitors and generating jobs in the tourist sector. Many Eastern European countries, such as the Czech Republic, Hungary and Poland, have developed successful tourism sectors after the fall of communism in 1989. The richest countries still control the international tourism market. France, Spain, the US and Italy have remained on top of the list of the most sought-after tourist destinations, although their position has been threatened by the growth of tourism in the East. China is already the world's fourth largest tourist destination and was the country with the highest spending in this sector in $2019^{3}$. One of the reasons for the growth of tourism in Asia is the extraordinary development of Asian economies. Europeans are increasingly travelling to Oriental and Southeast Asian countries. Even within the same vast Asia-Pacific region, tourists from Singapore, South Korea, Japan, Australia and China tend to favour holiday

${ }^{3} 2019$ was another year of strong growth, although slower compared to the exceptional rates of 2017 and 2018 (6\% increase in both years). Demand was slower mainly in advanced economies and particularly in Europe. Uncertainty surrounding Brexit, geopolitical and trade tensions, and the global economic slowdown, weighed on growth. 2019 was also the year of major shifts in the sector with the collapse of Thomas Cook and of several low-cost airlines in Europe. All regions enjoyed an increase in arrivals. The Middle East $(+8 \%)$ led growth, followed by Asia and the Pacific (+5\%). International arrivals in Europe and Africa (both $+4 \%)$ increased in line with the world average, while the Americas saw growth of $2 \%$. However, in 2020, the world faced an unprecedented global health, social and economic emergency due to the COVID-19 pandemic. Travel and tourism are among the most affected sectors. In an unprecedented shock to the tourism sector, the COVID-19 pandemic has cut international tourist arrivals in the first quarter of 2020 to a fraction of what they were a year before. Asia and the Pacific, the first region to suffer the impact of COVID-19, saw a 35\% decrease in arrivals in the first quarter of 2020. The second-hardest hit was Europe with a $19 \%$ decline, followed by the Americas (-15\%), Africa (-12\%) and the Middle East (-11\%). Current scenarios for the year point to declines of $58 \%$ to $78 \%$ in international tourist arrivals in 2020 , depending on the speed of the containment, the duration of travel restrictions and the re-opening of national borders, although the outlook remains highly uncertain. The plunge in international travel puts 100 to 120 million direct tourism jobs at risk (UNWTO, 2020a; 2020b). 
destinations such as Indonesia, Malaysia, Thailand and the Philippines. This creates an intense tourist flow that bypasses Europe and the Americas.

Going against the stereotype of one-sided cultural, economic and political currents, a more befitting image of a decentralized network of alternate and multidirectional flows manifests itself. This network enhances the contingent nature of economics and politics, and suggests that nowaday's complex global systems may easily shift power between East and West. However, the rapid rise in the number of tourists travelling across the globe can either bring wealth and prosperity to a region or lead to human exploitation and environmental damage. Tourism may serve to impose a culture over other or to evade the laws and regulations of one's country of origin. In Thailand and Cambodia, for instance, tourist inflows from Japan, Europe and America have given rise to a lucrative sex tourism trade that exploits women and children within a context where legal and protective mechanisms are rarely accessible. Conversely, tourism can also mean respect and appreciation for the culture that is visited, thus strengthening cultural exchanges between different peoples. Tourism can revive local cultures, promote the cultural heritage of a region, and lead to the reinvention of traditions and customs that have long been cast aside. According to Cohen and Kennedy, traditions that survive are those that have been reinvented, they are not the same as their original prototype (COHEN \& KENNEDY, 2000: 228). We shall now discuss some of the ways tourism is viewed as a social and cultural phenomenon, as well as a vehicle for the invention and reinvention of traditions.

\section{Tourism as a social and cultural practice.}

In The Elementary Forms of Religious Life (1915), Emile Durkheim described how religious rites, sacred objects and beliefs could be distinguished from the objects and practices of daily life, which he called profane. Places of devotion and objects used in religious rites are addressed with a degree of respect that is in stark contrast with those other daily life objects and practices. The function of sacredness is to bring communities together and reinforce shared beliefs by means of ceremonies and rituals. Profane does not receive this exceptional treatment, but finds resonance in common sense and daily life experiences. In order to enter the realm of sacredness, one must renounce ordinary life and embrace the extraordinary. In pre-modern societies, religion worked as a sphere within the realm of extraordinariness. Some would experience extraordinariness through pilgrimage, whereas many others would experience it in local religious festivities, Holy days and their rituals. One must not forget that, in English, the term 'holiday' is derived from the combination of two words: 'Holy' and 'day'.

In $21^{\text {st }}$ century Western societies, it is quite unlikely that religion can set the boundaries between what is commonplace and what is extraordinary. Instead, Harrison claims that holidays and travel are a means we resort to in order to seek extraordinary experiences, that is, to encounter sacredness (HARRISON, 1995: 240). We visit tourist attractions to contemplate them with veneration; we expect that by vacationing, we will be suddenly carried away from our daily work routine into an extraordinary landscape of pleasure, from where we will arise and return regenerated. Before leaving, we make intense preparations for the holiday experience; when we return, we share objects, images and memories. Holidays and tourism are part of those social practices that have a specific function and 
meaning in modern societies, their cultural significance is shared and disseminated among most citizens of Western societies.

Although Durkheim's theories can be applied to the phenomenon of tourism, in reality, tourists are not worshippers nor do they frequent an exclusive place of devotion. Tourists collect experiences that can range from contemplating natural landscapes (such as the Natural Park of Peneda Gerês or the Alps) to a historical re-enactment (such as the Medieval Fairs of Santa Maria da Feira and Óbidos), from in loco observation of the way of life of indigenous populations (such as the Maoris or Sami) to EuroDisney's fairy tale attractions. At Disney's theme parks, daily life conventions are suddenly lifted, whilst visitors engage in childlike behaviours that bring them closer to the need for the extraordinary in a secular world. Such as in the Middle Ages, contemporary tourists have become pilgrims and tourist attractions have turned into places of regeneration and authenticity, which is in fact often (though not always) illusory, ephemeral and artificial (HARRISON, 1995: 240 et seq.).

However, not all tourists seek illusory experiences. On the contrary, they might deliberately seek an authentic experience, be it a historical re-enactment, an immersion into an indigenous culture or even a specific workplace. For instance, Tokyo stock exchange can be visited by tourists, who can watch transactions, take a guided tour and play a stock trading simulation game, using news and corporate information in a virtual securities market. Historical re-enactments can portray with authenticity the life of slaves on a $19^{\text {th }}$ century plantation field or some Old West rodeo. $21^{\text {st }}$ century tourism involves more and more observation and/or participation in real life re-enactments, whether related to the past or present. John Urry reiterates that tourists are contemporary pilgrims searching for the authenticity of other times and other places, far from those times and places that make up their daily lives (2002: 9). This can be witnessed by the popularity of safaris in Africa, glamping in the desert or tours to the jungle tribes of the Amazon.

Social media, photography, digital technologies, glossy magazines and television bring to our homes images of tourist devotional places that trigger a wanderlust in us. These media ensure that tourists already know what they will visit long before they leave, what they should expect to see when they get there, and how they shall interpret a certain attraction. Tourists are encouraged to act as collectors, the bearers of a checklist of places to visit and things to do. Those who visit more places collect a greater amount of mementos, passport stamps, photographs and posts on social networks, thus acquiring a new social and even professional status, as social media travel influencers. Places that are visited or are to be visited are represented with a particular discourse that identifies and distinguishes them from others: Paris is represented as the City of Lights and romance; Spain as the land of passion and flamenco; the Maldives as a kind of tropical paradise; India as a haven of mysticism and spirituality; China as the bastion of the mysterious East; Brazil as an Eden of sensuality and joy. Attractions such as Niagara Falls, Stonehenge, the Eiffel Tower or Miami Beach are also culturally demarcated territories, shaped by common meanings, transformed by the economy and technology, quite distant from their original meaning. According to John Urry, what we experience is based on pre-existing cultural images, where the physical object in itself has become nearly invisible (2002: 59).

In all these territories, those people who find jobs and earn their income in tourist development activities, embrace it with joy. Those who live in a tourist destination, but 
do not reap direct tourist benefits, can somehow take pride in showing off their culture to visitors and thereby learning from them about other cultures. However, those who have been displaced from their homes and do not benefit from tourism financially can see visitors as invaders and may antagonize them. Moreover, visitors can demand high standards of lodging and services, in a clear contrast with the actual living conditions of local inhabitants. This intricate network of shared (often conflictual) meanings, different individual experiences, and political and business decisions, interwoven around the geographic space itself, gives rise to an invented territory that can be known as Algarve, Porto, Douro, Mustique, Bora Bora, Bali or Dubai.

\section{Cultural territories and the identities of tourism.}

The seemingly homogeneous identity expressed in the term "tourist" only exists within its contingent relationship with the hosts that receive, accommodate and often tolerate tourists in their territories. One cannot be a tourist and a host at the same time, because being a tourist means in its core to be away from home or from their place of origin; being a tourist means not being a host. The concept of tourist as a homogeneous identity constructed by the mass travel industry has been challenged, as there is not a single type of tourist, but a wide range of identities associated with travel (APOSTOLOPOULOS, LEIVADI \& YIANNAKIS, 1996). A usual definition is that which distinguishes 'tourists' from 'travellers'. Travellers visit places whilst searching for authenticity, either by observing natural landscapes or by taking part in local culture. Tourists, on the other hand, seek fun in the company of other people with similar goals. In this construction of identities, tourists are generally associated with superficial, nonauthentic experiences, provided by the mass travel industry, whereas travellers are identified with ancient pilgrims, seeking to understand and participate in the cultures they visit (COHEN, 1996: 90). Hence, the distinction created between tourists and travellers is translated into a permanent antagonism, in an identity logic based on mutually exclusive dichotomous pairs.

The spatial markers that build identities are equally important. For instance, in the $19^{\text {th }}$ century, men could transit freely in public spaces, whereas women were often limited to their homes. Servants occupied certain spaces within a bourgeois home that were clearly separated from the spaces used by their masters. Being a servant or a woman meant taking up spaces delineated by their social identity, that is, it meant inhabiting certain cultural territories. In the case of tourism, an example of cultural territory are the all-inclusive resorts, such as the ones found in the Caribbean, Cape Verde or Southern Spain, where lodging, entertainment, food, beverages, sports and leisure can all be found within the same delimited space and are included in the package. Tourists are restricted to a specific area and rarely ever meet local inhabitants, unless the latter work in the resort. In this example, differences between the two identities (tourist/host) are displayed explicitly and marked in space.

Tourism enhances the reclamation and preservation of cultural identities associated with a territory threatened by globalization, desertification or marginalization. Some examples are Tana Toraja, Bali, Ibiza, Madeira, Nazaré, Ria de Aveiro, Obidos and the Vicentine Coast. This can involve the appropriation and adaptation of elements from other cultures, in 
order to create something that is not purely traditional nor exclusively modern, but a culture in a constant state of dynamism. A non-condescending perspective should acknowledge that cultures, as well as their accompanying cultural identities, evolve continuously in any part of the world and should not be expected to remain perfectly stagnant in time.

The tourism industry is aggressive in its ceaseless pursuit of increasingly exotic and remote new attractions and destinations, such as Papua New Guinea, the Amazon or even Antarctica. When tourism is established in a region, its peoples and cultures are marketed, typecast by advertising and sold to an international tourism consuming public. International mass tourism has triggered one of the largest population movements ever, where millions of occasional travellers from industrialized nations seek, on the outskirts of globalization, living vestiges of their imagination, embodied as exotic, erotic or as Rousseau's "noble savage". French Polynesia, for instance, is described in tourist language as a tropical paradise with pristine beaches, a place of purity and charm, where people live blissfully, away from civilization and close to nature, in a culture that is unchanging, harmonious and sustainable. This myth of the primitive man that resists the threats of civilization not only overlooks real living conditions of local inhabitants, but also describes a culture that has actually never existed. The descriptions about many tourist sites away from Western metropoles resonate the Orientalist discourse analysed by Edward Said, as well as the anthropological monologues based on a redemptive ethnography.

Tourism takes place in a border zone that is not natural, which exists in order to be discovered by tourists, as all borders are human constructs. Most tourists, mainly those who travel in organized groups, do not only visit an actual country; they visit selected tourist destinations instead, that are located within a border zone ${ }^{4}$. Tourist border zones are fluid, they may change over time; by definition, no migrants live therein, but a recurring wave of temporary travellers, a population of tourists in constant movement and renewal. The collective identity category and the presence of tourists is permanent, but each single individual comes and goes constantly. The resident population is somewhat permanent, but they must get out of their daily routine to meet tourists, to sell their goods and services or to exhibit themselves and their culture. The tourist border zone is a cultural territory that resembles a stage in anticipation of a spectacle, both for the tourist audience and for the inhabitant actors. Thus, inhabitants also have to come and go constantly in this tourist border zone. Notwithstanding, the perceptions of both groups are not the same, as what is a territory of leisure and exoticism for tourists, is a territory of work and profit for inhabitants.

What the tourist discourse announces as being authentic, pure and unknown has been, in fact carefully fabricated, sold and advertised. The inhabitants of the Maldives, Salvador da Bahia, Bali and the French Polynesia, among others, acknowledge this thirst of tourists for the exotic and authentic. Thus, they present themselves and their cultures in a way that properly reflects preconceived tourist representations. From the outside, tourists visit primitive inhabitants; from the inside - according to the inhabitants' perspective - tourism

4 We have adapted here the concept of the border zone described by Gloria Anzaldúa (1987), Guillermo Gómez-Peña (1993), Emily Hicks (1991) and Coco Fusco (1989), who developed their theories based on the border between the United States and Mexico, as a place of migration between two countries. 
is a means to achieving economic development and ensure subsistence. However, the richer and more modern local populations become, the less interesting they will become for tourists. Therefore, the less money they will get from tourism. If the abovementioned peoples renounce their role as the exotic noble savage, they risk losing their major source of income. What most inhabitants do in this situation is to collaborate with the production of a tourist discourse and representation, staged as a strategic essentialism. However, tourists are not a passive agent in this process: they collaborate with the inhabitants by tacitly accepting the fictional tourist enactment. The tourist border zone is a territory of cultural invention on a wider scale. Tourists wish to experience a fictional past that is untouched by globalization. Hence, the industry invents versions of this utopian past and turns them into tourist consumption assets. Tourists do not travel to experience the postcolonial present nor the territories that emerge from economic development; they travel in order to enjoy a colonial past lost in time.

That said, tourists travel to a border zone between their 'civilized' culture and 'another' culture that is 'exotic' and 'savage', in order to explore a fantastic territory of the Western imagination. In reality, this 'other' 'savage' is the post-colonial subject, who has long travelled in the opposite direction, as people from Sub-Saharan Africa, India, South America, China and the Maghreb have migrated to Western metropoles many decades ago. Paradoxically, the Western elite seems to be ready to spend thousands of euros travelling thousands of miles in order to encounter those they might easily meet in their hometown, in their day-to-day lives. In Western metropoles, the efforts of more privileged socioeconomic classes to avoid acknowledging the presence of other ethnicities in their midst are striking. This takes the form of self-segregation in private condominiums, upscale suburban towns or gated communities. When they are forced to observe 'other' people who surround them, they normally do so by means of a selective representation that emphasizes poverty and marginalization, in detriment of those 'others' that ascended to middle class, working, studying and generating wealth. Westerners enjoy going to ethnic restaurants and folkloric shows, as long as they take place in restricted and legitimate spaces. The elite avoids seeing the 'other' in first world cities, but on their vacation, they travel to tourist border zones expressly aiming to observe that same 'other'. According to the discourse of hegemony, the 'other' in Western territories is a source of criticism; the 'other' in the territory of their alleged distant origin is a source of pleasure and instagrammable moments collected as trophies. In fact, this is a longstanding phenomenon, existing already for well over a hundred years in the United States, where Native Americans living in their reserves, become exotic and romantic, but when they go to urban metropoles they are generally perceived as undesirable. In a third world space, the 'other' is domesticated, works for tourists, is frozen in time or out of time, fabricating a westernized version of their culture, where they participate as mere actors (BRUNER, 2005: 191-5).

While travelling for adventure, experience, status or exploration of the exotic 'other', tourists can bring back a hypothetical, intangible, decontextualized and pristine 'other', who they own and control through the stories they tell and the images they display. Tourists insert the post-colonial subject into a new narrative frame, where tourists become the heroes of the trip and the 'other' is the object of their demand. Thus, it is extremely important to guide the attention of the tourism sector, as well as of the research on the 
topic, towards host communities, more or so than towards the motivations of the tourist, that is to say, this perspective should become truly intercultural.

\section{Opportunities for development through intercultural tourism.}

Speaking of intercultural tourism is somewhat redundant, as tourism always implies a contact between different customs, uses, traditions and structures of feeling, that is, between different cultures. In order to illustrate this topic, we will use the case of Portugal, a country with approximately 10 million inhabitants that, in 2019, welcomed a total of 27 million tourists, $7.3 \%$ more than in 2018 , a significant advance in the pace of growth, according to data from the National Statistics Institute (INE) 5 .

The economic and commercial exploitation of culture is increasingly guided by the reinvention of traditions arising out of controversial exogenous and political interests. Regarding the intercultural study of tourism, two fundamental approaches can be addressed. The first approach is interested in economic matters and addresses the problem of change, development and modernization. The second approach relates to the cultural dimensions of tourism, that is not seen as a mere instrument of destruction, but as a potential factor for creativity and reinvention. The combination of these two approaches concludes that the reification of culture through tourism may not always destroy it but, instead, transform culture and boost its growth. However, some major challenges remain: the issue of cultural authenticity; the cultural homogenization of mass tourism; the relationship between economic improvement and cultural impoverishment. Tourism can respond creatively to local cultures and positively influence their path towards development, because barring all changes is as infeasible as sanctioning all modifications. Therefore, an intermediate position becomes a strategy of productivity and sustainable development. We shall call this perspective "intercultural tourism".

Nowadays, the notion of 'traditional' is often associated with an idea of 'authenticity', which is not always correct. Conversely, 'traditional' and 'typical' are two concepts that are

\footnotetext{
${ }^{5}$ In 2019, tourism revenues increased to 4.28 billion euros in Portugal. In terms of stay, hotels continue to lead the choice, concentrating around 58 million stays, ahead of local accommodation with 10 million stays. Rural tourism counted with 1.0 million overnight stays. When it comes to growth, hostels stood out with overnight stays skyrocketing $23.5 \%$ (INE). Most of the tourists kept coming from the United Kingdom, with a total of 9.38 million people, rising 1.5\% when compared to 2018, followed by Germany, with 5.88 million guests, and Spain, with 5.22 million. In terms of growth, the highlight goes to the North American (29.2\%), Canadian $(27.6 \%)$ and Irish $(26 \%)$ markets. With tourism expanding more and more, the national authority "Tourism of Portugal" approved the construction of 105 new hotels. In the specific field of sustainability, Portugal received the 2019 Accessible Tourist Destination Award during the $23^{\text {rd }}$ General Assembly of the UNWTO, held in St. Petersburg. In the World Economic Forum's 2019 Tourism Competitiveness Report, an in-depth analysis of tourism in over 130 countries, Portugal achieved unprecedented results when, for the first time, ranked first in the quality of tourist infrastructure and $12^{\text {th }}$ in the global competitiveness ranking (WEF). During the COVID-19 outbreak, the Portuguese Government has been taking strict public health measures to protect the population. General behaviour guidelines were enacted, in which all people must adopt a 2 meter social distance, whereas the use of face masks became mandatory in public transport and services, shops, supermarkets, and in all closed and/or crowded spaces. All services should take hygiene and sanitisation measures according to the indications of the Directorate-General of Health, with specific recommendations for each sector of the economy. In tourism, the "Clean \& Safe" seal, defined by the Tourism of Portugal, was implemented, granting tourists greater security and confidence in accommodation, services and attractions.
} 
often mixed up, as they are not necessarily synonyms. The maintenance of authenticity is a phenomenon directly related to the process of continuity and change; tradition not always corresponds to authenticity, as it can be invented or reinvented; 'typical' is often artificial, imported or transposed, therefore, not authentic. Likewise, after the industrial revolution, Western societies tended to invent traditions, in order to establish a connection with the past and with a lost community identity (HOBSBAWN \& RANGER, 1988: 9). In Portugal, we can highlight the 'typical' carnival of Ovar, famed for its samba schools and dancers dressed in tropical Brazilian fashion, who parade under the cold rain and wind, in the height of the winter of Northern Portugal.

The main purpose of intercultural tourism consists in favouring the knowledge of tangible and intangible assets of local, regional or national cultures. This is how they should be perceived, not to meet visitors' needs and expectations, which is often the case, as in the example above. A growing interest has been perceived in considering 'intercultural' as a process that manifests itself on occasions where different groups are led to confrontation so that later they reconcile their points of view and meanings. Tourism, with its multiple border territories, becomes an excellent opportunity for practicing intercultural processes and for inventing new forms of cultural expression.

\subsection{The risks of cultural commodification and (over) mediated activities.}

Greenwood questions the possibility of culture being considered a commodity. Indeed, everything that is marketed is a product stemming from a combination of production factors. However, this is not so evident when tourists are attracted by a local cultural characteristic, such as the Vila Franca de Xira bull run, the appearance of the Virgin Mary in Fatima or the congress of folk medicine in Vilar de Perdizes. Hence, Greenwood claims that culture is a peculiar, altered and often destroyed commodity, when addressed as tourist attraction (1989: 172-3). In fact, culture commodification, either as a natural resource or as service is potentially destructive and should be reconsidered by all those involved in the tourism industry. A good example would be the landscape and environmental concerns in the Algarve and the Troia Peninsula that were only taken into account in the late $20^{\text {th }}$ century, after decades of ecological and urbanistic neglect.

In the past, relationships between travellers and their hosts were considerably more direct than they normally are in contemporary tourism. Travel conditions were largely determined by hospitality conventions, much more than by travellers' rules and requirements. The advent of mass tourism changed it all, to a point where, in certain situations, the distinction between tourists and hosts became almost irrelevant. Indeed, while opting for cruises, hotel chains, resorts, theme parks, shopping malls and casinos, tourists are frequenting places that are only vaguely foreign. Conversely, local communities are often prevented from engaging in any type of relationship with visitors. In some cases, their work is no longer necessary, as importing labour, catering, entertainment, technology and other goods required by tourists has become easier. As stated above, if the representation of local inhabitants is deemed desirable, it would be limited to the cultural picturesqueness and elements of local colour, according to the expectations that tourists create and bring along with them.

Some popular tourist destinations can now be considered 'tourist cultures', due to the predominance of cultural influences of visitors, such as Ibiza, Dubai, the Cayman Islands 
or Acapulco, with little or no relationship with the local population amidst which they have been established. These communities are based on recreational lifestyles, such as beach, nightlife and ecotourism resorts, evoking those theme parks which are designed deliberately as fantasylands. But the development of heritage tourism can also generate 'tourist cultures' alienated from reality, as it is frequently associated with the invention of communities erected from idealized images of the past, such as Sortelha, Óbidos, Monsanto and other villages that have been renovated for tourist purposes in the countryside of Northern and Central Portugal. In many cases, these tourist communities have acquired a strong cultural symbology, but were rarely built in a vacuum, as they have arisen from - and sometimes in stark contrast with - preexisting communities, widely ignored in the decision, design and execution of tourism projects.

Tourism is an increasingly mediated activity, depending on the intervention of agents who are neither hosts nor visitors. This is obvious when we consider large-scale tourist enterprises, such as theme parks, resorts and the recuperation of historical centres. The motivations for the tourism mediation activity vary, as well as the ideas and values that these agents aim to convey, in their attempt towards balancing the interests of tourists and those of the communities they visit. However, most agents tend towards invisibility, such is the case of owners of large resorts in the Algarve and Alentejo or the real estate agents of Óbidos, Lisbon and Porto. This trend is stimulated in part by the desire of keeping - at least on the surface - the most traditional host/guest relationship possible. Nevertheless, the agent's invisibility is also motivated by the desire of concealing inequality in the distribution of wealth derived from tourism. This has become almost axiomatic in the tourism industry: those who profit the most with its development are those who suffer the least with its impact.

\subsection{Heritage and the development of intercultural tourism.}

In Portugal, the tourism industry re-emerged in the eighties of the $20^{\text {th }}$ century, in a format far removed from its roots in the 19th century, when predominant cultural values emphasized the preservation of cultural heritage and the picturesque aspects of Portuguese rural life. In the $20^{\text {th }}$ century, tourism was no longer an isolated activity and became an economic and political issue. Therefore, the fascist regime of Estado Novo sought to promote the image of a traditional, hospitable and peaceful country, isolated from foreign influences and stagnated in time, especially from the 1940s onwards. Only in the seventies, tourism in Portugal took the form of an industry, when the traditional view of popular culture as folklore was replaced by the values of popular mass culture, based on the promotion of a 'sun and sea' product. Notwithstanding, some elements of the original Portuguese approach to tourism and culture remain at the core of current policies.

The Portuguese cultural heritage, both tangible and intangible, constitutes a strong identity element and a powerful resource to attract national and foreign tourists. Compared to other European countries, Portugal does not have a large number of monuments and museums to offer its visitors. Thus, the attention of travel agents has turned to the preservation and exploitation of the valuable heritage resources available, which include castles, sacred art, gastronomy, wine, architecture, tiles and fado, among other practices of what can be generally called the Portuguese way of life, i.e., the Portuguese culture. We 
should not forget that Portugal is amongst the fifteen countries in the world with the most tangible and intangible cultural heritage listed by UNESCO, as follows:

\section{Table 1}

\begin{tabular}{|l||l||}
\hline \multicolumn{1}{|l|}{ Tangible Heritage } & Intangible Heritage \\
\hline \hline Historic Centre of Angra do Heroísmo, 1983 & Fado, 2011 \\
\hline \hline Jerónimos Monastery and Belém Tower, 1983 & Mediterranean cuisine, 20136 \\
\hline \hline Monastery of Batalha, 1983 & Cante (singing) from Alentejo, 2014 \\
\hline \hline Convent of Christ of Tomar, 1983 & $\begin{array}{l}\text { Traditional Portuguese musical shaker art, } \\
\text { Historic Centre of Évora, 1988 }\end{array}$ \\
\hline \hline Alcobaça Monastery, 1989 & Black pottery of Bisalhães, 2016 \\
\hline \hline The cultural landscape of Sintra, 1995 & Portuguese falconry art, 2016 \\
\hline \hline Historic Centre of Porto, 1996 & Estremoz clay figures, 2017 \\
\hline \hline $\begin{array}{l}\text { Prehistoric Rock-Art Site of the Côa Valley, } \\
\text { 1998 }\end{array}$ & \\
\hline \hline Laurel Forest of Madeira, 1999 & \\
\hline \hline Historic Centre of Guimarães, 2001 & \\
\hline \hline Alto Douro Wine Region, 2001 & \\
\hline \hline $\begin{array}{l}\text { The Landscape of the Pico Island Vineyard, } \\
\text { 2004 }\end{array}$ & \\
\hline \hline The Garrison Border Town of Elvas, 2012 & \\
\hline \hline University and the upper city of Coimbra, 2013 & \\
\hline \hline $\begin{array}{l}\text { Sanctuary of Bom Jesus do Monte of Braga, } \\
\text { 2019 }\end{array}$ & \\
\hline $\begin{array}{l}\text { Royal Buildings of Mafra, Convent, Garden } \\
\text { and Hunting Park, 2019 }\end{array}$ & \\
\hline
\end{tabular}

Portugal was essentially a rural country for many years, not acquainted with industrialization. Agriculture, though obsolete, was the main source of income for a large part of the economically active population until recently. Hence, for structural reasons, Portuguese rurality also turned out to be a symbolic resource to be valued and preserved in the tourism industry, as it can be seen in the Alentejo, Minho, Azores and Portuguese Beira villages. Intercultural tourism is an appropriate response to the maintenance of local and regional identity, as the imitation of mass tourism models that occurred in the Algarve - following the examples of Costa del Sol, the Greek Islands or the French Riviera - has only led to an uncharacteristic offer, without competitiveness or identity, thus reducing the territory and the profit margin.

Research on tourism as an intercultural phenomenon tends to focus on international aspects and on the impact of the relationship between wealthy Western visitors and developing nations, who crave their wealth. The assumption of this relationship is described as an important aspect of contemporary tourism, whose growth often followed Western imperialist routes, when travelling was one of the many privileges

\footnotetext{
6 With Spain, Morocco, Italy, Greece, Cyprus and Croatia.
} 
of the colonizer. However, this can be reductive, as it obliterates the increasing dependence of the so-called developed Western countries, where Portugal is included, along with Spain, France or the United Kingdom, in relation to tourism, in a phenomenon that makes the notions of host and visitor even more ambiguous, especially when one bears in mind the intense economic flows of domestic tourism. In Portugal, for instance, international tourism represents $70 \%$ of tourist demand, with the domestic market accounting for the remaining 30\%. Residents of Portugal spent a total of around two billion euros on domestic tourism in 2018. The Northern region of the country (the Norte) was the most visited destination by domestic tourists in 2019, with approximately 2.8 million visitors, with Lisbon and the surrounding region attracting about 2.2 million domestic visitors that same year (INE).

These calls for attention are an opportunity for the productive intervention of Social and Human Sciences in the intercultural tourism industry, both in the case of Portugal and beyond. They are firstly aimed at contributing to improving the offer, enhancing local territories and communities, and privileging residents as dynamic actors interested in the tourist offer. The risks and opportunities involved in the process of transforming monological affirmative actions into dialogical transforming actions through intercultural tourism can be summarized along these ten guidelines:

Table 2.

\begin{tabular}{|c|c|}
\hline \multicolumn{2}{|c|}{ Intercultural Tourism } \\
\hline Risks & Opportunities \\
\hline Local culture limited to picturesque. & $\begin{array}{l}\text { Implementation of inclusive, dialogue } \\
\text { generating projects, by acknowledging } \\
\text { integration, diversification rand } \\
\text { complementarity as critical tools to improve } \\
\text { offer. }\end{array}$ \\
\hline Predominance of cultural influence of visitors. & $\begin{array}{l}\text { International tourism promotion, through } \\
\text { digital media campaigns, trade marketing } \\
\text { actions and initiatives of economic diplomacy, } \\
\text { with updated and scientifically reviewed } \\
\text { information on local history, traditions, } \\
\text { customs and ethnographies. }\end{array}$ \\
\hline Idealized image of the past. & $\begin{array}{l}\text { Historically correct marketing strategies, } \\
\text { reinforced by critical collections, carried out in } \\
\text { the field, with scientific oversight. }\end{array}$ \\
\hline Cultural symbolism detached from reality. & $\begin{array}{l}\text { Creation of comprehensive circuits across the } \\
\text { region, supported by sustainable equipment } \\
\text { and infrastructure, with broad and inclusive } \\
\text { themes, easy access and adequate signage. }\end{array}$ \\
\hline Deletion of existing communities. & $\begin{array}{l}\text { Engage local populations in decision-making } \\
\text { processes and in the execution, consolidation } \\
\text { and development of tourism projects, } \\
\text { privileging local resources, both human and } \\
\text { material. }\end{array}$ \\
\hline Dependence on international guests. & Focus on the domestic market. \\
\hline
\end{tabular}




\begin{tabular}{||l||l||}
\hline $\begin{array}{l}\text { Unequal distribution of tourism generated } \\
\text { wealth. }\end{array}$ & $\begin{array}{l}\text { Accountability of mediating agents, promoting } \\
\text { actions of social entrepreneurship. }\end{array}$ \\
\hline \hline Cultural commodification. & $\begin{array}{l}\text { Promote UNESCO tangible and intangible } \\
\text { cultural heritage, safeguarded by rigorous } \\
\text { environmental and urbanistic measures. }\end{array}$ \\
\hline \hline Invented traditions. & $\begin{array}{l}\text { Reinvented and creative traditions that offer } \\
\text { authentic though innovative experiences. }\end{array}$ \\
\hline \hline Prohibit all changes/Accept all modifications. & Productive and sustainable development. \\
\hline \hline \multicolumn{2}{|c|}{ Intercultural Tourism } \\
\hline \multicolumn{2}{|c|}{} \\
\hline
\end{tabular}

\section{Conclusions}

Addressing tourism as an intercultural business is both an opportunity and a challenge. The opportunity to develop routes of cultural tourism while empowering and engaging communities in the protection of cultural heritage; the challenge to enhance sustainable tourism, with an impact on employment, economic growth, poverty reduction, environmental protection and the general preservation of authenticity in culture and heritage. In fact, cultural tourism is one of the newest trends in the industry, supported by a postmodern style of demand, growing levels of cultural capital, rising educational levels, a desire for direct forms of experience, and global mobility. In the present context of international tourism, there is an increased interest for the use of literature, arts, crafts, heritage, and traditions, as well as for tangible and intangible cultural products and practices in general, to promote places and destinations, while preserving the expressions, memories and identities of social-cultural territories. The cultural turn in tourism and related business practices is likely to lead to the development of economic strategies where culture and creativity play a relevant role in the branding of competitive cities, regions and countries, using innovation and technology to promote their international image.

According to UNWTO, there is a new trend in the profile of tourists: more and more, they are solo and multigenerational travellers, as a result of aging populations and single households, pursuing a healthy lifestyle, valuing walking, wellness and sports tourism. The rise of the access economy and of the importance of sustainability has led to travelling with the purpose of either 'changing', in a quest for authenticity and transformation, living like the locals; or 'showing', by collecting moments, experiences and destinations. New intercultural perspectives must be offered in tune with the shifting preferences of modern visitors, while creating alternative routes that are not usually offered to mass tourists, thus fostering sustainability and economic growth, with a more effective branding and marketing strategy.

A strategic, integral, and inclusive sense of identity and territory sustains cohesive communities, capable of addressing their own needs and developing their own resources, within the complex framework of globalized tourism. By recognizing the cultural value of different sections of the community - including groups that face social and economic exclusion - cultural resources and heritage that could otherwise be seen as ordinary become exceptional. And the exceptional is what tourists seek, as opposed to the commonplace routine of everyday life. 


\section{References}

ABDALLAH-PRETCEILLE, M. (2006) "Interculturalism as a Paradigm for Thinking about Diversity". Intercultural Education, 17:5 (475-83).

ANZALDÚA, G. (1987) Boderlands/La Frontera, The New Mestiza. São Francisco: Spinsters/Aunt Lute Foundation.

APOSTOLOPOULOS, Y.; LEIVADI, S; YIANNAKIS, A. (eds) (1996) The Sociology of Tourism: Theoretical and Empirical Investigations. London: Routledge.

BARANOWSKI, S. (2001) Being Elsewhere: Tourism, Consumer Culture, and Identity in Modern Europe and NorthAmerica. Ann Arbor, Michigan: University of Michigan Press.

BELL, C.; LYALL, J. (2001) The Accelerated Sublime: Landscape, Tourism and Identity. Westport: Praeger Publishers.

BRUNER, E. (2005) Culture on Tour: Ethnographies of Travel. Chicago: The University of Chicago Press.

BURNS, P. (2002) An Introduction to Tourism and Anthropology. London and New York: Routledge.

COHEN, E. (1996) "A phenomenology of tourist experiences". In Y. Apostolopoulos, S. Leivadi and A. Yiannakis (eds), The Sociology of Tourism: Theoretical and Empirical Investigations. London: Routledge.

COHEN, R.; KENNEDY, P (2000) Global Sociology. Basingstoke: Palgrave.

CROUCH, D. (ed.) (2000) Leisure and Tourism Geographies: Practices and Geographical Knowledge. London: Routledge.

CROUCH, D.; LUBBREN, N. (eds.) (2003) Visual Culture and Tourism. Oxford: Berg Publishers.

DANIEL, A. C.; RAMOS, F. (2002) "Modelling Inbound International Tourism Demand to Portugal", International Journal of Tourism Research 4:3 (193-209).

DERVIN, F., GAJARDO, A.; LAVANCHY, A. (eds.). (2011). Politics of Interculturality. Newcastle-upon-Tyne: Cambridge Scholars Publishing.

DERVIN, F.; ZEHAVIT, G. (eds.) (2016) Intercultural Competence: Alternative approaches for different times. London: Palgrave MacMillan.

DUGAY P. (1997) Doing Cultural Studies: The Story of the Sony Walkman. London: Sage/Open University.

DUGAY, P. (2007) Organizing Identity. London: Sage Publications.

FUSCO, C. (1989) “The Border Art Workshop/Taller de Arte Fronterizo, Interview with Guillermo GómezPeña and Emily Hicks", Third Text 7 (53-76).

GÓMES-PEÑA, G. (1993) The New World Border: Prophecies, Poems, and Loqueras for the End of the Century. San Francisco: City Lights Books.

GREENWOOD, D. (1989) "Culture by the Pound: An Anthropological Perspective on Tourism as Cultural Comoditization", in Valene Smith (ed.), Hosts and Guests: The Anthropology of Tourism. Philadelphia: University of Pennsylvania Press.

HALLAM, Elizabeth; STREET, Brian (eds.) (2000) Cultural Encounters: Representing Otherness. London and New York: Routledge.

HARRISON, D. (1995) “Tourism, Capitalism and Development in Less Developed Countries, in L. Sklair (ed.), Capitalism and Development. London: Routledge.

HICKS, E. (1991) Border Writing: The Multidimensional Text. Minneapolis: University of Minnesota Press.

HOBSBAWN, E.; RANGER, T. (eds) (1988) The Invention of Tradition. Cambridge: Cambridge University Press. HOLLIDAY, A. (2011) Intercultural Communication and Ideology. London: Sage.

HOLLIDAY, A. (2013) Understanding Intercultural Communication. London: Routledge.

HOWARD, P. (2003) Heritage: Management, Interpretation, Identity. London: Continuum.

IBANEZ, B. P.; SAENZ, M. C. L. (eds.). (2006). Interculturalism: Between Identity and Diversity. Bern: Peter Lang.

IMBERT, P. (ed.) (2014). Multicultural Interactions: Canada and the World, Politics and Literature. Ottawa: University of Ottawa Press.

INE - Instituto Nacional de Estatística (2019), Estatística do Turismo, https://www.ine.pt/xportal/xmain?xpgid=ine_tema\&xpid=INE\&tema_cod=1713 (accessed August 2020).

ROJEK, C.; URRY, J. (eds.) (2002) Touring Cultures: Transformations of Travel and Theory. London and New York: Routledge.

SAID, E. (2004 [1978]) Orientalismo: Representações Ocidentais do Oriente, trans. Pedro Serras. Lisbon: Livros Cotovia. 
SANTOS, Maria da Graça Poças (2010) Turismo Cultural, Territórios e Identidades. Porto: Afrontamento.

SARMENTO, C. (2014). "Interculturalism, Multiculturalism and Intercultural Studies: Questioning Definitions, Repositioning Strategies". Intercultural Pragmatics 11:4 (603-18).

SARMENTO, C. (2016). "Intercultural Polyphonies against the 'Death of Multiculturalism': an Essay on Concepts, Practices and Dialogues". In Fred Dervin \& Zehavit Gross (eds.), Intercultural Competence: Alternative approaches for different times (121-42). London: Palgrave MacMillan.

SARMENTO, C. (ed.). (2010). From Here to Diversity: Globalization and Intercultural Dialogues. Newcastle-uponTyne: Cambridge Scholars Publishing.

SMITH, V. (ed.) (1989) Hosts and Guests. The Anthropology of Tourism. Philadelphia: University of Pennsylvania Press.

UNWTO - United Nations World Tourism Organization (2020a). World Tourism Barometer and Statistical Annex, volume 18 , issue 1 , January.

UNWTO - United Nations World Tourism Organization (2020b). World Tourism Barometer and Statistical Annex, volume 18 , issue 2 , May.

URRY, J. (2002) The Tourist Gaze. London, California and New Delhi: Sage.

WEF - World Economic Forum (2020), The Travel \& Tourism Competitiveness Report 2019, https://www.weforum.org/reports/the-travel-tourism-competitiveness-report-2019 (accessed August 2020).

WILLIAMS, R. (1961) The Long Revolution. London: Chatto and Windus.

WILLIAMS, R. (1976) Keywords: A Vocabulary of Culture and Society. London: Fontana. 